\title{
Assessment of Acceptability and Satisfaction of Patients for Government Hospital Diets
}

\author{
Shreshtha Muraal*, Dr. Vinti Davar** \\ *Research Scholar, **Associate Professor \\ Department of Home Science, Kurukshetra University, Kurukshetra
}

\begin{abstract}
Nutrition plays a major role in protecting health and slowing disease progression. Hospital diets play an indispensable role in patient recovery and well-being. But providing appropriate nutrition in the hospital meal is a particularly challenging task because of the diverse dietary needs of the patients. The proposed study was done with the objective to assess the satisfaction of the patients towards the diet and overall acceptability of the hospital diet being served to the patients. The study was conducted in one government hospital in Chandigarh city. Sixty self structured questionnaires based on four types of diets viz. regular, diabetic, low protein-low sodium and high protein diets were filled with the cooperation of patients after seeking due permission from hospital authorities. Questionnaires were tabulated and analyzed using SPSS12. The sensory evaluation was done by using 5-point Hedonic Scale. From the data, it was deduced that 56.67 per cent of the patients were satisfied from the quantity given whereas only few patients (26.67\%) were satisfied with the desired consistency of diets. After analyzing sensory aspects of the diets, it was found that the mean of freshness, taste, appearance and aroma were $2.93 \pm 0.841,2.55 \pm 0.946,2.68 \pm 1.016$ and $2.48 \pm 0.873$ respectively. The mean of overall acceptability of the served diets was $2.66 \pm 0.932$. The findings of the study show that almost all the patients were satisfied with the type of diets they were getting, amount of the feed and time taken for the delivery of the meal. The major issue for the dissatisfaction among patients were monotonous, repetitive and insipid food which requires serious and determined attempts of dietetics and Food Service Department.
\end{abstract}

Key words: Patient, Diet, Satisfaction level, Sensory evaluation.

\section{Introduction}

Healthy food is almost as important to healing as competent medical care, also healthy eating habits play a critical role in preventing chronic diseases such as heart disease and diabetes etc. Good dietary service based on the application of optimum nutritional requirements contributes significantly to the care and recovery of patients. Dietetics and Food Service Department is an integral part of the hospital supportive services which provides normal and therapeutic diets to the patients. Efficient delivery of proper, quality diet to each type of patient is the primary work of dietetics department resulting in great satisfaction of patients and their caretakers. Foodservice quality is significantly correlated with overall patient satisfaction (Sheehan-Smith, 2006). It is well recognized that food and other aspects of foodservice delivery are important elements of the patients' overall perception of the hospital experience. The greater patients' expectations are met, the more satisfied they seem to be (Lau \& Gregoire, 1998; Fottler et al., 2001). Therefore, provision of foodservices that not only meet but exceed the expectations of the patient should be considered essential for quality hospital foodservices (Fallon et al., 2008).

A thorough knowledge of the varied dimensions of hospital foodservice satisfaction is needed to understand patient expectations and promote the health and nutritional status of patients (Wright, Connelly, \& Capra, 2006). Dubé et al. (1994) found that food quality was the best predictor of patient satisfaction, followed by customization and attitude of the staff that deliver menus. The perception of food quality can depend on several different attributes, including meal taste, variety, flavour, texture and the perception of choosing a healthy meal (Wright et al., 2006). Disease status, poor appetite, gastrointestinal intolerance, fatigue, early satiety and taste alterations often affect intake in a hospital setting (McLymont et al., 2003; Williams et al., 1998). Clinical dieticians often advise malnourished, hospitalized patients to consume 'small, frequent meals' or snacks every few hours to encourage oral intake and meet nutritional needs. Promoting optimal nutritional status can lead to faster recovery times and reduced hospital costs (Sullivan, Nelson, Bopp, Puskarich-May, \& Walls, 1998; Giner et al., 1996; Johansen et al., 2004). European research on food and nutritional care in hospital has recognized that it is necessary to define responsibilities, promote staff qualification, enable patients' participation in nutritional decisions, and integrate the health care team into nutritional care (Ovesen et al., 2001). 


\section{Objectives}

The proposed study was done with the objectives to:

- adjudge the satisfaction of the patients towards the hospital diets and

- assess overall acceptability of the hospital diets being served to the patients in government hospital.

\section{Methodology}

The study was conducted in the month of June and July 2013 in a government hospital of Chandigarh city. The name of the hospital is intended to be kept secret as per the directives maintained by the hospital authorities. The data was collected after seeking the written permission from the hospital administration. Sixty questionnaires were filled with the cooperation and keen interest of patients. Self structured pre-tested questionnaire, semi-structured interview with the patients as well as with their attendants and observation method were used in the study to draw relevant conclusions. General information, demographic profile and eating habits of patients, satisfaction with menus mainly: food variety, taste, texture, temperature, freshness, appearance, aroma, portion size, service timeliness and style of service, food preferences and presentation by the food service department were assessed through the questionnaire. The subjects were divided on the basis of type of diet given to them, namely: regular, diabetic, high-protein and low protein-low sodium diets. The regular diet is modified from the balanced diet recommended by ICMR. It provides all the nutrients in slightly higher amounts than recommended for a healthy male sedentary worker. Patients suffering from pyrexia and dizziness were given and treated under group of regular diets. High protein diet was served to the patients having malnutrition, seizure attack or trauma. Diabetic diets were provided to the diabetic patients excluding Type-I diabetic and gestational diabetic patients. Diabetic diet is as close to the regular diet as possible but slightly low in carbohydrates, but adequate in other food principles. Similarly, low protein-low sodium diets were given to acute and chronic renal failure and nephritis patients except the patients undergoing treatment for kidney transplant and dialysis. For sensory evaluation, a 5-point hedonic scale allowed subjects to rate quality from very good to very poor. Score 5 indicated extremely liked, 4 - liked slightly, 3- neither liked nor disliked whereas 2 and 1 indicated disliked slightly and extremely disliked respectively. The information gathered was tabulated and statistically analysed to deduce results.

\section{Results \& Discussion}

Table 1: Type of Diet Served to the Patients of Government Hospital

\begin{tabular}{|l|l|l|}
\hline Type of diet & No. of Patients $(\mathbf{n}=\mathbf{6 0})$ & Percentage $(\%)$ \\
\hline Regular & 5 & 8.33 \\
\hline Diabetic & 18 & 30 \\
\hline Low Protein -Low Sodium & 10 & 16.67 \\
\hline High Protein & 27 & 45 \\
\hline
\end{tabular}

Table 1 indicates that out of total selected subjects, 8.33 per cent patients suffering from pyrexia were getting regular diet. Diabetic and sodium-restricted diets were being served to 30 and 16.67 per cent of the patients respectively. Around 27 per cent patients having malnutrition, epileptic fit and fractures were given high protein diet.

Table 2: Satisfaction level of Patients towards Diets of Government Hospital

\begin{tabular}{|l|l|l|l|}
\hline Satisfaction Parameters & Responses & No. Of Patients (n=60) & Percentage (\%) \\
\hline Amount & Yes & 34 & 56.67 \\
\hline & No & 26 & 43.33 \\
\hline Consistency & Yes & 16 & 26.67 \\
\hline & No & 44 & 73.33 \\
\hline Time of Service & Yes & 39 & 65.00 \\
\hline & No & 21 & 35.00 \\
\hline Variety & Yes & 37 & 61.67 \\
\hline & No & 23 & 38.33 \\
\hline
\end{tabular}

Further, the data from Table 2 revealed that only 56.67 per cent patients were satisfied with the quantity of the food given and only 26.67 per cent patients were satisfied with the consistency of the served diet. It was elicited from the data that only 65 per cent subjects were satisfied with the timing of delivery of feeds. During discussion with the patients, most of them were not comfortable with the serving time of breakfast which was 7 to 8 a.m. They also added that they do not feel hungry so early. According to Bulzaka (2008), mostly the programs of hospital room service systems begin serving around 6:30-7 am and go into the early evening until 6:30-7 pm. However, some programs run 24 hours a day, seven days a week. Hours of operation should be 
decided based on patient population; most important is that the majority of patients have what they want to eat when they want to eat it (Norton, 2008). Moreover, the results show that only 61.67 per cent patients were satisfied with the variety of diets and they informed the investigators that they were not satisfied with the monotonous feed of porridge, almost daily in breakfast.

Capra et al. (2005) stated that the food does not have to be of a high quality for the patient to be satisfied, as satisfaction is a comparison between an expectation and a reality or experience. Patients may expect the food to be very poor, and as a result will be inclined to rate 'ordinary' food well. It has also been suggested that patients tend to overinflate their satisfaction depending on any number of methodological influences (Sitzia, 1999).

Each hospital foodservice institution is unique and interventions must be customized to the specific patient population's needs and perceptions (Wright et al., 2006). The data pertaining to sensory evaluation of the diets (Table 3) indicate that the mean scores of freshness, taste, appearance and aroma of government hospitals were $2.93 \pm 0.841,2.55 \pm 0.946,2.68 \pm 1.016$ and $2.48 \pm 0.873$. The overall acceptability of patients towards the served diets was $2.66 \pm 0.932$ in government hospital patients.

Table 3: Sensory Evaluation of Served Diets in Government Hospital

\begin{tabular}{|l|c|}
\hline Parameters & Mean \pm S.D \\
\hline Freshness & $2.93 \pm 0.841$ \\
\hline Taste & $2.55 \pm 0.946$ \\
\hline Appearance & $2.68 \pm 1.016$ \\
\hline Aroma & $2.48 \pm 0.873$ \\
\hline Overall acceptability & $2.66 \pm 0.932$ \\
\hline
\end{tabular}

\section{Summary and Conclusion}

The findings of the study show that almost all the patients were by and large satisfied with the type of diets they were getting, amount of the feed and time taken for the delivery of the meal. The major issues for the dissatisfaction among patients were monotonous, repetitive and insipid food. Also early breakfast timings were not appreciated by most of the patients which can easily be amended.

\section{References}

[1]. Buzalka, M. (2008, December 1). You've tossed your trayline...now what? Food Management, pp.32-35.

[2]. Capra, S., Wright, O., Sardie, M., Bauer, J., \& Askew, D. The acute hospital foodservice patient satisfaction questionnaire. The development of a valid and reliable tool to measure patient satisfaction with acute care hospital foodservices. Foodservice Research International., 2005, 16, 1-14.

[3]. Dubé, L., Trudeau, E., \& Belanger, M. C. (1994). Determining the complexity of patient satisfaction with foodservices. Journal of the American Dietetic Association, 98, 394-399.

[4]. Fallon, A., Gurr, S., Hannan-Jones, M., \& Bauer, J. D. (2008). Use of the acute care hospital foodservice patient satisfaction questionnaire to monitor trends in patient satisfaction with foodservice at an acute care private hospital. Nutrition \& Dietetics, 65 , 41-46.

[5]. Fottler, M. D., Ford, R. C, \& Roberts, V., Ford, E. W., Spears, J. D. (2000). Creating a healing environment: the importance of the service setting in the new consumer oriented healthcare system. Journal of Healthcare Management, 45, 91-106.

[6]. Giner, M., Laviano, A., Meguid, M. M., \& Gleason, J. R. (1996). In 1995 a correlation between malnutrition and poor outcome in critically ill patients still exists. Nutrition, 12, 23-29.

[7]. Johansen, N., Kondrop, J., Plum, L. M., Bak, L., Norregaard, P., Bunch, E., Baernthsen, H., Andersen, J. R., Larsen, I. H., \& Martinsen, A. (2004). Effect of nutritional support on clinical outcome in patients at nutritional risk. Clinical Nutrition, 23, 539-550.

[8]. Lau, C. \& Gregoire, M. B. (1998). Quality ratings of a hospital foodservice department by inpatients and post discharge patients. Journal of the American Dietetic Association, 98, 1303-1307.

[9]. McLymont, V., Sharon, C., \& Stell, F. (2003). Improving patient meal satisfaction with room service meal delivery. Journal of nursing care quality, 18(1), 27-37.

[10]. Norton, C. (2008). Why room service? Is it for your hospital's foodservice operation? Market Link, 27, 1-11.

[11]. Ovesen L, Beck AM, Balknas UN, Furst P, Hasunen K, Jones L, et al: Food and nutritional care in hospitals: how to prevent undernutrition-report and guidelines from the Council of Europe. Clin Nutr 2001, 20(5):455-460.

[12]. Sheehan-Smith, L. (2006). Key facilitators and best practices of hotel-style room service in hosptials. Journal of the American Dietetic Association, 106, 581-586.

[13]. Sitzia, J. (1999). How valid and reliable are patient satisfaction data? An analysis of 195 studies. International Journal for Quality in Health Care, 11, 319-328.

[14]. Sullivan, D. H., Nelson, C. L., Bopp, M. M., Puskarich-May, C. L., \& Walls, R. C. (1998). Nightly enteral nutrition support of elderly hip fracture patients: a phase I trial. Journal of the American College of Nutrition, 17, 155-161.

[15]. Williams, R., Virtue, K., \& Adkins, A. (1998). Room service improves patient food intake and satisfaction with hospital food. Journal of Pediatric Oncology Nursing, 15(3),183-189.

[16]. Wright, O. R. L., Connelly, K. B., \& Capra, S. (2006). Consumer evaluation of hospital foodservice quality: an empirical investigation. International Journal of Health Care Quality Assurance, 19(2), 181-194. 